\title{
PROGRESSIVE FINANCING IN INDONESIAN ISLAMIC MICROFINANCE INSTITUTIONS: IMPROVED MONITORING OR DISTINCTIVE COMMERCIALISATION?
}

\author{
Muhammad Miqdad Robbani ${ }^{1}$, Mahdiah Aulia ${ }^{2}$ and Fatiya Rumi Humaira ${ }^{3}$ \\ ${ }^{1}$ Universitas Indonesia, Indonesia, muhammad.miqdad@ui.ac.id \\ ${ }^{2}$ International Islamic University Malaysia, Malaysia, mahdiah.aulia@gmail.com \\ ${ }^{3}$ University of Manchester, United Kingdom, rumihumaira@gmail.com
}

\begin{abstract}
Microfinance institutions (MFIs) play pivotal roles to providing financing and services to micro and small enterprises (MSEs) in Indonesia. Islamic MFIs, which follow Shariah principles in their operations, aim not only to provide financing, but also to improve the socioeconomic conditions of poor people. There is heightened interest in the factors influencing the development of MFIs, such as relationship lending. This study aims to explore the effectiveness of such lending and the uniqueness of the implementation of social purpose in Islamic MFIs. The paper adopts a quantitative methodology, using cross-sectional survey data from 1,001 microloan borrowers from five MFIs, three of which are Islamic MFIs which provided financing in 13 regions in Indonesia in 2018. The results show that Islamic MFIs do not differ in the implementation of relationship lending. Furthermore, there is a likelihood that they are able to be more focused on profit-oriented transactions ensuring sustainability, due to their unique characteristics, as they have Baitul Maal with the social instruments of zakat, infaq and sadaqa to provide social-oriented transactions to improve outreach to the poor. The study enhances our understanding and adds knowledge to the existing literature on Islamic MFIs, especially in Indonesia.
\end{abstract}

Keywords: Islamic microfinance institutions, Micro and small enterprises, Baitul tamwil, Relationship lending. JEL Classification: G20; G21; G51.

Article history:

Received : : September 28, 2019

Revised : February 26, 2020

Accepted : July 6, 2020

Available online : August 25, 2020

https://doi.org/10.21098/jimf.v6i3.1183 


\section{INTRODUCTION}

\subsection{Background}

Micro and small enterprises (MSEs) are the engines for economic growth and employment in Indonesia. They enhance competition and entrepreneurship, which in turn promote productivity and efficiency in the economy (Beck, Kunt, \& Levine, 2005). According to Bank Indonesia (2015), micro enterprises are businesses with assets of less than 50 million rupiah and revenues of less than 300 million rupiah. On the other hand, small enterprises are businesses with assets of between 50 and 500 million rupiah and revenues in the range of 300 million to 2.5 billion rupiah. However, Ascarya and Sanrego (2007) propose for another classification, super micro enterprises, with assets of less than 10 million rupiah, while micro enterprises are businesses with assets that range between 10 and 100 million rupiah. The classification for micro enterprises is argued to be too broad and not fully represent the lowest income group. Furthermore, a typical microloan was merely in the range of 300,000 to 1 million rupiah. Ongoing critics of MSE classification point out that there are different interpretations of MSE definitions, as well as arguments as to whether there should be a super micro enterprise group. Moreover, the parameters by which they are defined, such as assets and revenue, are measured in nominal terms and are highly subject to dynamics in price level and economic development, which suggests that classification needs to be updated periodically. Nonetheless, formally established definitions used by the corresponding ministry are the most common references used.

MSEs contributed $93.91 \%$ of domestic employment and $46.43 \%$ of GDP in Indonesia in 2017 (Ministry of Cooperation and Small and Medium Enterprise of The Republic of Indonesia, 2017). These figures show their crucial role in supporting economic stability and growth. However, they face various obstacles in fully achieving their potential. The challenges to MSEs to expand and grow their businesses are mostly related to the lack of access to financing and to the adaption of technology. In 2014, it was estimated that around 60-70\% of MSEs did not have access to financing from banks (Bank Indonesia, 2015). Moreover, the bank financing criteria do not match MSEs needs, since they need to maintain their stability and efficiency (Chalid, Sulung, Robbani, \& Hambali, 2019). This situation means MSEs cannot access bank financing (Robbani, Anggriyani, Sekardhani, \& Nikmah, 2019). Therefore, non-bank financial institutions such as microfinance institutions (MFIs) are important to bridge the financing gap and support MSEs.

One of the most successful MFIs, which is frequently benchmarked in terms of best practice, is Grameen Bank in Bangladesh, which targets micro and small enterprises. The main features of MFIs are that they lend funds in small amounts; their targets are either individuals or groups; the period of financing is relatively short; and there are additional social development programs for MSEs (Hassan \& Renteria-Guerrero, 1997). Furthermore, there are MFIs that provide financing according to Shariah principles, known as Islamic MFIs. These retain the basic operational formats of MFIs; however, there are also differences, such as the prohibition of interest and the collection of funds from Islamic social funds e.g. zakat and waqf.

There are certain issues pertaining to the operational activities of MFIs. First, they face an adverse selection problem due to asymmetric information because of 
the lack of formal MSE documents. Sufficient information is important in order to assess the credit risk of customers, so MFIs face greater risks in financing MSEs without adequate assessment. However, they can address this problem with the use of the lending technology called relationship lending (Berger \& Udell, 2002). Such lending enables lenders to acquire information over time through repeated lending relationships to consequently to better assess credit risk and reduce information asymmetry $(\mathrm{Hu}, \mathrm{Lian}, \& \mathrm{Su}, 2016)$. MFIs are able to extract soft information from their repeated interactions. Furthermore, Petersen and Rajan (1994) found that stronger relationships correlate with greater credit availability, which benefits MSEs.

The second issue is the uniqueness of Islamic MFIs. The Financial Services Authority (FSA) of Indonesia defines an MFI as a financial institution established especially for MSEs, with its aim being not merely profit but also social and economic empowerment in society. Ahmed (2002) explains that the objective of Islamic MFIs is to serve the poorest groups in Muslim society and improve their economic condition. As the result, Islamic MFIs have distinctive features which are not found in non-Islamic ones. They are separated between socially-oriented and commercially-oriented activities, therefore dividing the organisations into two main parts: Baitul Maal and Baitul Tamwil. The socially-oriented role is delivered through the zakah instrument, which is distributed by Baitul Maal, while commercially-oriented aspects are executed through Baitul Tamwil. With regard to the previous discussion, this paper therefore aims to examine whether these distinct mechanisms of Islamic MFIs could lead to MFIs pursuing larger loan sizes as an indirect form of cross-subsidy between Baitul Maal and Baitul Tamwil (Ascarya, 2018).

The financing facility is important for MSEs and a higher level of lending by MFIs would accommodate this need. Higher credit availability could be the result of implementation of relationship lending, as information asymmetry decreases and confidence in financing MSEs increases. Having said that, the intention to operate on a fully profit-oriented basis could also be a reason for increased MFI credit availability.

\subsection{Objective}

The reason behind higher credit availability is an important issue related to the operation of Islamic MFIs, and has been discussed in several studies. Hiatt and Woodworth (2006) and Aigbokhan and Asemota (2011) found that borrowers who had experienced a longer history with the MFI had relatively high economic wealth compared to new borrowers. Furthermore, Agarwal, Chomsisengphet, Liu, Song, \& Souleles (2018) report that the duration of the relationship between borrowers and lenders influences credit availability; a longer relationship results in higher credit availability. There have also been studies on the distinctive characteristics of Islamic MFIs. Ascarya (2018) argues that they are more focused on targeting profitability than their counterparts, since they separate socially-oriented activities from their core business.

However, there has been little discussion on these issues with regard to Islamic MFIs in Indonesia. Islamic institutions tend to provide more financing to 
MSEs rather than conventional ones (Shaban, Duygun, Anwar, \& Akbar, 2014), and MFI credit availability can be influenced by relationship lending and also its unique mechanism. The relationship between these two factors in relation to credit availability from Islamic MFIs has not yet been reported, so it is not clear which one is apparent and influencing the current situation. This paper aims to investigate the effectiveness of relationship lending and the existence of the distinctive mechanism in Islamic MFIs. The study therefore intends to assess whether Islamic MFIs take advantage of relationship lending to strengthen their relationship with customers, and whether the level of customer welfare influences MFI credit availability as the implementation of MFIs' preference to seek profitability. The literature review is presented in Section II, followed by discussion of the methodology in Section III. The results and discussion are elaborated in Section IV, and the paper is concluded in Section V.

\section{LITERATURE REVIEW}

\subsection{Background Theory}

\subsubsection{Theory of Microfinance}

In general, microfinance is the practice of making micro-sized loans by microfinance institutions (MFIs), mainly to small and micro enterprises. It has been evolving as a solution for low-income households facing obstacles in accessing loans from banks, as they lack formal documents to be used as collateral, given their background characteristics and the nature of their business. As microfinance is able to increase financial access for the grassroots population, it has been associated with poverty reduction (Korth, Stewart, Van Rooyen, \& De Wet, 2012).

\subsubsection{Double Bottom-Line and Triple Bottom-Line}

As the objective of microfinance is not only profit-oriented, MFIs faces several challenges. The approach through which MFIs handle their multi-objective nature is described as the 'double bottom-line', whereby they strive to meet both the social and financial goals of their business (Foose \& Greenberg, 2008). Furthermore, as global awareness of environmental issues has increased, MFIs have also embarked on a triple bottom-line, focusing not only on their social and financial goals, but also on the environmental impacts of their borrowers' activities funded by the microloans disbursed (Schuite \& Pater, 2008).

In Zeller and Meyer (2002), the term 'critical triangle of microfinance' was introduced, as MFIs struggled to simultaneously address the issues of financial sustainability, outreach and impact. The most resilient MFIs were considered to be those who managed to create synergy among the three issues, although some trade-off was unavoidable. There are various reasons why MFIs might seem to favour borrowers with higher wealth. Despite the possibility of mission drift, it is evidenced that individuals with higher wealth submitted more applications for loans compared to poorer individuals, therefore improving the probability of their being granted loans by the MFI. In terms of the cost, time and effort needed to apply for loans, wealthier individuals are at advantage. Therefore, reducing the cost of loan applications for poorer individuals has been proven to be beneficial in 
increasing their chances of accessing more loans through the joint-liability group mechanism which is frequently implemented in the most successful MFIs.

On the other hand, the cost issue for MFIs in funding poorer individuals does not relate to their high risk, but to the cost of obtaining information on their creditworthiness. Furthermore, to address this issue, business development training is often held, despite the increased costs of conducting the training. Nonetheless, if MFIs become more sustainable as a result of such training, then borrowers will use their services more, which in turn will increases MFI financial sustainability. If MFIs operate for longer, they will have a higher chance of improving their efficiency and providing more attractive products and services. As a result, MFIs' impact will also increase. This potential for synergy between the sustainability-outreach-impact aspects has been proposed as a cure for the microfinance triple-bottom line, with the suggestion that the government help in creating a supportive environment for both MSEs and MFIs to be able to develop further (Zeller \& Meyer, 2002).

\subsubsection{Commercialisation in Microfinance}

The double bottom-line and triple bottom-line mainly concern how to balance MFIs' social and financial objectives. Too heavy a focus on the financial objective might risk an MFI becoming commercialised and going through a mission drift. Such a drift is defined as the likelihood of MFIs pursuing economies of scale by disbursing larger average loan sizes, which would be interpreted as them prioritising 'larger' customers over smaller ones, who should be who they serve (Armendariz \& Szafarz, 2011). Fundamentally, mission drift takes place because social enterprises (MFI being one such) have dual objectives that aim for both social and commercial targets. MFI mission drift could be prevented actively, apart from through standard governance mechanisms (Cornforth, 2014).

However, in Islamic MFIs, there is another scheme in providing financing for borrowers which leads to larger loan sizes. Mission drift is not relevant in Islamic finance since organisations separate social and profit-oriented programmes. Baitul Maal focuses on the social functions of collecting and distributing zakah and on voluntary charities such as infaq and sadaqoh, while Baitul Tamwil functions as a financial intermediary by managing funding and saving activities through various Islamic financial products and services needed by those on low incomes (Wulandari, 2019)

\subsection{Previous Studies}

\subsubsection{Microfinance and MSE Financing in Indonesia}

Historically, rural banking in Indonesia was initiated in 1895, with BRI established just one year before. During the 1997 Asian financial crisis, a great number of companies shut down, which left a red mark on the bank portfolio. It was during that time that MSEs played significant role as the engine of economic growth in Indonesia. Consequently, banks began to give greater priority to MSE financing (Masyita \& Ahmed, 2013). 
However, serving MSEs and low-income households presents specific difficulties. The main challenges, as identified by Obaidullah (2008), are i) the collateral system, which is challenging for MSEs; ii) the high financing costs for banks; and iii) the high processing costs. With limited financial access to banks, microfinance has been promoted as a solution for low-income households to be able to obtain loans and develop their businesses (Aigbokhan \& Asemota, 2011). Outcomes from microfinance practices include lower poverty rates and increased income growth, which have been proven globally, although the results differ by region (Weiss \& Montgomery, 2005). One of the channels through which microfinance has been able to achieve these outcomes is by financing MSEs. Generally, these are judged to be rather unattractive by banks due to their informal characteristics. For MFIs, however, MSEs are a suitable target market (Khandker, 2005). Furthermore, MSEs are able to achieve the financial sustainability of their businesses as the result of financing from MFIs (Yahaya, Osemene, \& Abdulraheem, 2011).

\subsubsection{Islamic MFIs in Indonesia}

Awareness of the Islamic financial services industry in Indonesia has been growing rapidly, although there remain persistent challenges in the market. Research has shown that the reason for certain Islamic commercial banks to have managed to perform well in Islamic banking has been down to human resources development (Seibel, 2008). The market for Islamic microfinance remains heavily concentrated on the large banks, who own 70 to 80 percent of the market share (Tamanni \& Haji Besar, 2019). Nonetheless, these commercial banks are still underperforming in the delivery of microfinance services, and the same problem is also found in Islamic rural banks. Primarily, the issues faced by Islamic MFIs are being able to achieve financial sustainability and to offer their clients suitable financial products.

On the other hand, Islamic cooperatives might be able to strategically deliver microfinance services, but clients are put at greater risk if they are not properly regulated. Therefore, there are two suggested methods for accelerating the growth of Islamic microfinance, namely i) assisting the Islamic commercial banks to offer microfinance services under a separate unit, or by ii) enhancing the supervision, internal control and associations of Islamic MFIs (Seibel, 2008).

Research has found that borrowers choose MFIs based on both economic and non-economic considerations (Masyita \& Ahmed, 2013). Economic-driven factors include the price of the loan (interest rate), loan size and collateral, while noneconomic factors include the profile of the loan officer, the method of payment, the speed of loan processing, distance and ease of application. A survey found that the top-ranked MFIs based on these criteria were the conventional Bank Rakyat Indonesia (BRI) (Masyita \& Ahmed, 2013), with second place taken by the Islamic Rural Bank (BPRS), third the Conventional Rural Bank (BPR) and fourth the Baitul Maal wat Tamwil (BMT). Currently, Islamic MFIs are continuously improving by adapting the best practices used in the banking industry.

There are two facets to Islamic MFIs, namely Baitul Maal and Baitul Tamwil. Baitul Maal focuses on social functions by collecting and distributing zakah and on voluntary charities such as infaq and sadaqoh, while Baitul Tamwil functions as a 
financial intermediary by managing funding and saving activities needed by low income people through various Islamic financial products and services (Wulandari, 2019). Baitul Maal, as the amil (zakah manager), collects zakah and charity from members, employees and the surrounding community, then distributes the funds according to their intended purposes through various programmes such as training, technical assistance and qard financing to develop the socioeconomic condition of the recipients (Ascarya, 2018).

\subsubsection{Relationship Lending in MFIs}

Relationship lending, or situations in which the borrower has a relationship with the lender, has been suggested to affect the outcome of lending policy, such as interest rates and credit availability (Agarwal et al., 2018). In order to fully understand the concept of relationship lending, choosing the appropriate indicator to measure it is necessary. Imai, Gaiha, Thapa and Annim (2010) measured the relationship variable as the length of time borrowers interact with the lender, by using a dummy variable equal to one if the borrowers had been with the MFI for a specific period.

Research on the benefits of relationship lending between MFIs and their borrowers is relatively limited. Hiatt and Woodworth (2006) found that borrowers who havd been with the MFI for at least one year, and thus had a stronger relationship than new borrowers, had relatively higher economic wealth. This finding is further supported by Aigbokhan and Asemota (2011), who similarly found that having a prior history with an MFI will improve the economic condition of borrowers. However, the channels of such benefit are yet to be examined; for example, whether having a relationship leads to lower interest rates and higher credit availability, which will allow borrowers to gain from lower borrowing costs.

Diamond (1991) found that borrowers who had a long relationship with lenders tended to be more eligible for loans, as the lenders have greater understanding about them. Such a situation will therefore lead to low risk for the lenders and low costs for the borrowers, thus creating a mutual benefit (López-Espinosa, Mayordomo, \& Moreno, 2017). Apart from lower interest rates, credit availability is also higher for borrowers with long-term relationships, as shown by Agarwal et al. (2018). It is argued that the existence of relationship lending helps lenders to monitor borrowers.

In terms of Islamic finance, Shaban et al. (2014) suggest that it tends to have better relationships with borrowers. The fact that Islamic financing does not depend on collateral should trigger financial institutions to maintain their relationship with borrowers in order to reduce asymmetric information.

\subsubsection{Commercial Side of Microfinance}

In conventional MFIs, the likelihood of mission drift is considered to rely on the age and size of the MFI. However, as the size of MFIs increases, there is higher tendency for such drift as an outcome of the pursuit of financial sustainability. Further research on MFI mission drift has found that MFIs need to balance achievement of their explicit social purpose, which lays the very basic foundation 
for their being, with the implicit task of reaching sustainability (Simatele \& Dlamini, 2019). It is continuously questioned whether MFsI might reach a state of financial sustainability without sacrificing the level of outreach.

On the other hand, Islamic MFIs such as BMT have the unique characteristic of two functions being performed by the institution. Ascarya (2016) explains that BMT is able to conduct holistic financial inclusion (HFI), which involves social inclusion through Baitul Maal and financial inclusion through Baitul Tamwil, in order to achieve its microfinance objectives. Moreover, Naceur, Barajas and Massara (2015) argue that Islamic microfinance such as BMT provides a more holistic framework to conventional microfinance in alleviating poverty and promoting a sound economic situation. Wijaya, Hakim, Saputro and Mulyadi (2019) found that the religiosity level of customers significantly influenced saving decisions in BMTs. The separation of the two functions of Baitul Maal and Baitul Tamwil should be taken into consideration when assessing mission drift in BMT.

\subsection{Conceptual Framework}

There are two main research questions in the paper. First, it intends to analyse the effect of the relationship of credit availability provided by Islamic MFIs in order to evaluate monitoring efficiency. The second aim is to examine the tendency to pursue profit over social objectives within Islamic MFIs. We use borrowers' individual wealth to represent the tendency of MFIs to be profit-oriented, as having borrowers with a relatively high level of wealth indicates that MFIs have a greater probability of making a higher profit as the result of cost efficiency from disbursing larger loans.

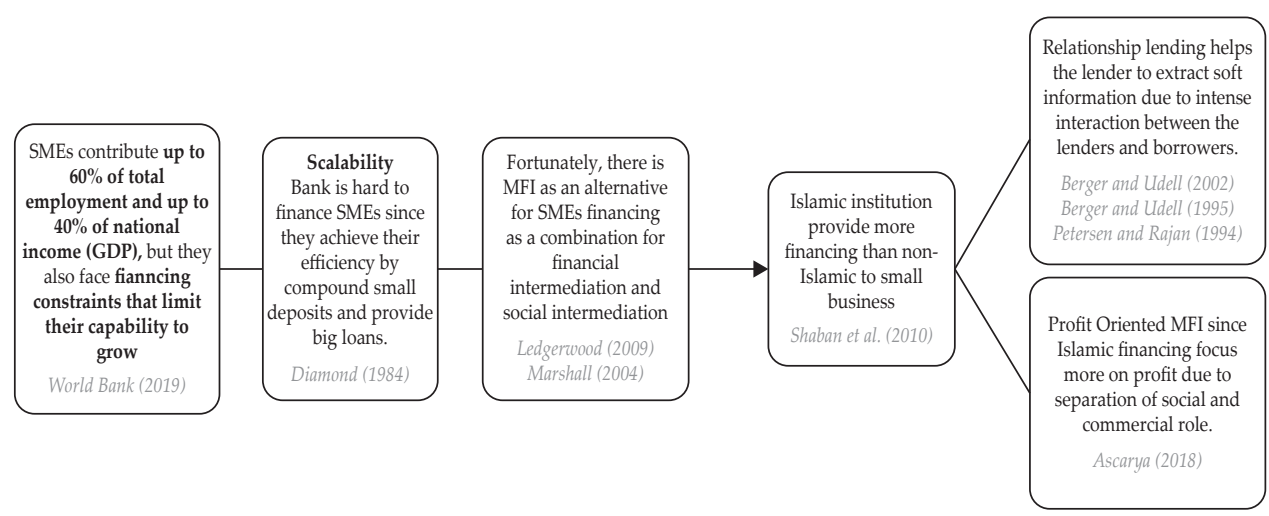

Source: Authors' elaboration (2019)

Figure 1.

Research Framework for Constructing the Model

The first one is the duration of the relationship between the borrower and the lender, which is measured using dummy variables equal to one if the borrower has interacted with the microfinance institution for specific periods. The longer borrowers have been involved in the loan market, the more likely it is that their 
business will qualify for loans (Diamond, 1991). Dynamic information from relationship lending between borrower and lender help lenders to conduct monitoring over time (Agarwal et al., 2018).

H1. The longer the relationship between lender and borrower, which implies better monitoring, the greater the likelihood of credit availability, since borrower risk is reduced through better assessment.

Second, the research also aims to examine the impact of borrower wealth on credit availability. Wealthier borrowers imply lower risk for the MFI and the possibility of higher profitability since credit amounts are higher than for the less wealthy. Therefore, the situation in which MFIs prefer to finance wealthier borrowers might represent their tendency to pursue profitability goals over social goals, because having borrowers with larger loans might decrease MFI credit outreach (Armendariz \& Szafarz, 2011). In Islamic microfinancing, such a situation might occur due to the fact that MFIs already have a separate social function, the Baitul Maal, therefore the Baitul Tamwil facet might be able to justify the tendency to provide large loans to ensure financial sustainability, although targeted borrowers should remain MSEs.

H2. MFIs' preference to finance wealthier borrowers due to their full profit oriented since social activities are distributed separately through Baitul Maal.

In order to examine the effect of Islamic MFIs, we interact the dummy variable with the relationship and borrower wealth variables. This enables us to observe the difference between Islamic and non-Islamic finance with regard to the specific variables.

\section{METHODOLOGY}

\subsection{Data}

The research uses cross-sectional survey data of 1,001 micro enterprise borrowers in 2018. The survey was conducted at five MFIs, three of which were Islamic, and which provided financing in 13 regions in Indonesia. The focus is on the Baitul Tamwil section of BMT, which concentrates on commercial borrowing activities. In term of akad, they use murabaha to provide financing for small to medium enterprise borrowers.

Variables were collected from the survey and divided into several characteristics. The first characteristic relates to individuals, consisting of proxies such as age, women dummy, head of family dummy, education, average individual expense, and total individual assets owned. This characteristic measured the individual qualities of borrowers, with a higher score indicating a wealthier borrower.

The next variable was business characteristics, which measured borrowers' business situation. It comprised number of employees, total sales, total business assets and profit. A higher score for this variable means indicated that the borrower's business is in good condition. Finally, we also included a relationship characteristic in the model to represent the relationship between the MFI and the borrower. The proxies used were business age and a dummy for the length of relationship with the borrower. A longer business age means that the borrower has a strong relationship with its stakeholders, while a longer relationship with the lender means that the MFI has sufficient information about the borrower. 


\subsection{Model Development}

We used model from previous research to predict the variables which determine credit availability (Petersen \& Rajan, 1994). However, for the proxy of credit availability, we used the percentage of loans approved instead of the probability of late trade debt (Ferri, Murro, \& Pini, 2020). The first model tends to identify the effect of the relationship variables on credit availability. In this case, we used a dummy for relationship length as the proxy. A longer relationship length represents a greater amount of information that can be extracted by the MFI. This information then can reduce asymmetric information and make the borrower more trusted (Diamond, 1984). In order to measure the Islamic effect on the model, we included a dummy for Islamic financing.

$$
Y_{i}=\beta_{0}+\beta_{1} D_{i}+\sum_{p=1}^{3} \sum_{k=1}^{q} \theta_{k, p} Z_{k, i, p}
$$

where $Y_{i}$ is the percentage of loan approved for loan $i$; $D_{i}$ is a dummy for Islamic financing for each loan $I$; and $Z_{k, i, p}$ are control variables, where $p=1,2$ and 3 respectively, representing individual, business and relationship characteristics for $\mathrm{k}$ number of variables and each loan $\mathrm{i}$.

We also interacted the Islamic dummy with the relationship variables to examine the specific effect of the variables on Islamic borrowers:

$$
Y_{i}=\beta_{0}+\sum_{k=1}^{r} \beta_{k, 1} X_{k, i}+\sum_{p=1}^{3} \sum_{k=1}^{q} \theta_{k, p} Z_{k, i, p}
$$

where $Y_{i}$ is the percentage of loan approved for loan $i$; $X_{i}$ is an interaction between the relationship variable and the Islamic dummy variable for each loan $I$; and $X_{k, i, p}$ are control variables, where $p=1,2$ and 3 respectively, representing individual, business and relationship characteristics for $\mathrm{k}$ number of variables and each loan $i$.

In the second model, we also used the individual characteristics which represent the wealth of the borrower, such as education level, average individual expense, and total individual assets owned:

$$
Y_{i}=\beta_{0}+\sum_{k=1}^{r} \beta_{k, 1} X_{k, i}+\sum_{p=1}^{3} \sum_{k=1}^{q} \theta_{k, p} Z_{k, i, p}
$$

where $Y_{i}$ is the percentage of loan approved for loan $i ; X_{i}$ is an interaction between the individual wealth indicator and the Islamic dummy variable for each loan I; and $X_{k, i, p}$ are control variables, where $p=1,2$ and 3 respectively, representing individual, business and relationship characteristics for $\mathrm{k}$ number of variables and each loan $\mathrm{i}$.

\subsection{Method}

For the research, we modified the questionnaire to make it easy and understandable for the respondents. For example, most of the answers related to total expense, 
profit, total assets and total sales are in the form of multiple choices instead of open questions. However, this could lead to limiting the variance in the variables.

We use limited dependent variable regression, namely Tobit regression, since the dependent variable has upper limit. Tobit regression is commonly used when the dependent variable has certain limit. The model in its simplest form can be stated as follows:

$$
\begin{aligned}
& Y^{*}=X \beta+\varepsilon \\
& y=y^{*} \text { if } y^{*} \geq 0, y=0 \text { if } y^{*}<0 \text { with } \varepsilon \sim N\left(0, \sigma^{2}\right)
\end{aligned}
$$

The general popularity of the model in labour economics, as well as in economics in general is, as in the binary choice model, traceable to its easy interpretation in terms of individual and firm choice; $\mathrm{y}^{*}$ represents either the demand or supply of a good, which will equal zero at a theoretically well-defined comer solution, or it is simply some other continuous choice which includes the option of not engaging in the consumption or activity at all (Moffitt, 1999). It also suits research focusing on consumer behaviour (Kinsey, 1981). In addition, another study used Tobit to examine the determinants of credit approval rates (Olagunju \& Ajiboye, 2010). Moreover, we used robust standard error to ensure that there was no effect from heteroscedasticity.

\section{RESULTS AND ANALYSIS}

\subsection{Results}

In this section, we present the descriptive statistics of the variables to better understand the regression. We then run the regression based on the two models previously developed. The first model develops the effect of the relationship variable on credit availability in order to examine the effectiveness of the relationship between the Islamic MFI and the borrower. A stronger relationship between borrower and lender tends to reduce asymmetric information in transactions (Petersen \& Rajan, 1994).

In the second model, we examine the potential uniqueness of the Islamic MFI social role. This hypothesis was developed by assuming that MFIs are starting to prioritise profitability; the intention can be examined when the wealth variables are significant in affecting credit availability for borrowers. Therefore, in this model, the individual wealth of borrowers is interacted with the Islamic dummy. 


\subsubsection{Descriptive Statistics}

Table 1.

Descriptive Statistics

\begin{tabular}{|c|c|c|c|c|c|c|}
\hline Variable & Obs & Mean & $S D$ & Min & Median & $\operatorname{Max}$ \\
\hline \multicolumn{7}{|l|}{ Dependent Variable } \\
\hline $\begin{array}{l}\text { Percentage of loans } \\
\text { approved }\end{array}$ & 1,001 & 96.066 & 13.795 & 1.000 & 100.000 & 100.000 \\
\hline \multicolumn{7}{|c|}{ Individual Characteristics } \\
\hline Age & 1,001 & 44.060 & 10.163 & 20.000 & 44.000 & 78.000 \\
\hline Women dummy & 1,001 & 0.569 & 0.495 & 0.000 & 1.000 & 1.000 \\
\hline Head of family dummy & 1,001 & 0.473 & 0.499 & 0.000 & 0.000 & 1.000 \\
\hline Education level & 1,001 & 3.265 & 1.157 & 1.000 & 3.000 & 7.000 \\
\hline $\begin{array}{l}\text { Average individual } \\
\text { expense }\end{array}$ & 1,001 & 1.583 & 0.324 & 1.000 & 1.500 & 4.000 \\
\hline $\begin{array}{l}\text { Total individual assets } \\
\text { owned }\end{array}$ & 1,001 & 5.094 & 1.236 & 0.000 & 5.000 & 8.000 \\
\hline \multicolumn{7}{|l|}{ Business Characteristics } \\
\hline Number of employees & 1,001 & 0.875 & 1.629 & 0.000 & 0.000 & 16.000 \\
\hline Total sales & 1,001 & 2.636 & 0.959 & 1.000 & 2.000 & 5.000 \\
\hline Total business assets & 1,001 & 2.186 & 1.551 & 1.000 & 2.000 & 6.000 \\
\hline Profit & 1,001 & 2.524 & 0.903 & 1.000 & 2.000 & 6.000 \\
\hline \multicolumn{7}{|c|}{ Relationship Characteristics } \\
\hline Business age & 1,001 & 11.880 & 8.672 & 0.000 & 10.000 & 50.000 \\
\hline $\begin{array}{l}\text { Relationship } 2 \text { - } 5 \text { years } \\
\text { dummy }\end{array}$ & 1,001 & 0.400 & 0.490 & 0.000 & 0.000 & 1.000 \\
\hline $\begin{array}{l}\text { Relationship }>5 \text { years } \\
\text { dummy }\end{array}$ & 1,001 & 0.325 & 0.468 & 0.000 & 0.000 & 1.000 \\
\hline \multicolumn{7}{|l|}{ Islamic Dummy } \\
\hline Islamic Dummy & 1,001 & 0.605 & 0.489 & 0.000 & 1.000 & 1.000 \\
\hline
\end{tabular}

Table 1 presents the descriptive statistics of the data. Most of the respondents received full financing based on their request, although some did not receive the full amount. This situation is represented by the mean of the percentage of loans approved, which is 96.066 percent. Furthermore, Table 1 shows that the majority of borrowers were women (56.9 percent). The education level is a rank variable, with zero indicating no schooling pursued, and seven indicating completion of a PhD program. The mean score (3.265) shows that on average borrowers finished junior high school. Average expenditure is also a rank variable, classifying monthly household expenses within a certain range. The lowest score is one, which represents monthly expenditure of below 1 million rupiahs, and the highest is six, which represents a figure of more than 10 million rupiahs. The descriptive statistics show that the maximum score which appears in the data is four, which indicates that the wealthiest respondents had an expenditure in the range of five to seven million rupiahs per month. The average level of borrowers' household expenses was one to three million rupiahs per month. Finally, the variable of total assets owned represents the level of borrowers' household assets (in the form 
of houses, farms, livestock, vehicles and brown goods). A higher level of assets signifies higher wealth. On average, borrowers typically have three assets.

Table 1 also shows the descriptive statistics of the relationship variables such as business age and dummy variables for duration of the relationship. Based on the data, an average borrower had been running their business for twelve years. In addition, $40 \%$ of the borrowers had had a relationship with the lender of between two to five years, while $32 \%$ had had a relationship for more than five years. In order to distinguish between Islamic MFI borrowers, we also found that the dummy for Islamic financing was $60.5 \%$, which means that the majority of the borrowers received financing from Islamic MFIs. It should therefore be noted that the breakdown between Islamic and non-Islamic MFI borrowers in the sample is unbalanced, although the difference is not great.

\subsubsection{Relationship Model}

In the first model, we examined the effect of the relationship variables on credit availability. We regressed the base model on credit availability, as represented by the loan amount variable in column (1). In column (2), we included the dummy for Islamic financing to examine the effect of implementing Shariah principles (through Islamic MFIs) on credit availability. Finally, we interacted the Islamic dummy with the relationship variables to examine their effect on Islamic financing in columns (3) and (4).

Table 2.

First Model Regression Results

\begin{tabular}{|c|c|c|c|c|}
\hline & (1) & (2) & (3) & (4) \\
\hline VARIABLE & $\begin{array}{c}\text { Loan } \\
\text { Amount }\end{array}$ & $\begin{array}{c}\text { Loan } \\
\text { Amount }\end{array}$ & $\begin{array}{c}\text { Loan } \\
\text { Amount }\end{array}$ & $\begin{array}{c}\text { Loan } \\
\text { Amount }\end{array}$ \\
\hline \multicolumn{5}{|l|}{ Individual Characteristics } \\
\hline Age & $\begin{array}{l}-0.269 \\
(0.374)\end{array}$ & $\begin{array}{l}-0.148 \\
(0.390)\end{array}$ & $\begin{array}{l}-0.156 \\
(0.389)\end{array}$ & $\begin{array}{l}-0.159 \\
(0.385)\end{array}$ \\
\hline Women dummy & $\begin{array}{l}-11.287 \\
(12.516)\end{array}$ & $\begin{array}{l}-12.665 \\
(12.689)\end{array}$ & $\begin{array}{l}-12.858 \\
(12.716)\end{array}$ & $\begin{array}{l}-12.791 \\
(12.765)\end{array}$ \\
\hline Head of family dummy & $\begin{array}{c}-4.637 \\
(11.635)\end{array}$ & $\begin{array}{l}-4.908 \\
(11.719)\end{array}$ & $\begin{array}{c}-5.235 \\
(11.729)\end{array}$ & $\begin{array}{c}-5.045 \\
(11.753)\end{array}$ \\
\hline Education level & $\begin{array}{l}-3.145 \\
(3.567)\end{array}$ & $\begin{array}{l}-0.854 \\
(3.823)\end{array}$ & $\begin{array}{l}-0.942 \\
(3.790)\end{array}$ & $\begin{array}{l}-0.942 \\
(3.777)\end{array}$ \\
\hline Average individual expense & $\begin{array}{l}-11.575 \\
(12.406)\end{array}$ & $\begin{array}{l}-8.789 \\
(12.550)\end{array}$ & $\begin{array}{c}-9.309 \\
(12.530)\end{array}$ & $\begin{array}{c}-8.822 \\
(12.530)\end{array}$ \\
\hline $\begin{array}{l}\text { Total individual assets } \\
\text { owned }\end{array}$ & $\begin{array}{l}-4.902 \\
(3.106)\end{array}$ & $\begin{array}{l}-5.513^{*} \\
(3.162)\end{array}$ & $\begin{array}{l}-5.397^{*} \\
(3.178)\end{array}$ & $\begin{array}{l}-5.391^{*} \\
(3.186)\end{array}$ \\
\hline \multicolumn{5}{|l|}{ Business Characteristics } \\
\hline Number of employees & $\begin{array}{l}-0.670 \\
(2.199)\end{array}$ & $\begin{array}{l}-0.572 \\
(2.364)\end{array}$ & $\begin{array}{l}-0.640 \\
(2.332)\end{array}$ & $\begin{array}{l}-0.586 \\
(2.356)\end{array}$ \\
\hline Total sales & 3.806 & 3.312 & 3.476 & 3.629 \\
\hline
\end{tabular}


Table 2.

First Model Regression Results (Continued)

\begin{tabular}{|c|c|c|c|c|}
\hline & (1) & (2) & (3) & (4) \\
\hline VARIABLE & $\begin{array}{c}\text { Loan } \\
\text { Amount }\end{array}$ & $\begin{array}{c}\text { Loan } \\
\text { Amount }\end{array}$ & $\begin{array}{c}\text { Loan } \\
\text { Amount }\end{array}$ & $\begin{array}{c}\text { Loan } \\
\text { Amount }\end{array}$ \\
\hline & $(5.239)$ & (5.309) & $(5.335)$ & $(5.360)$ \\
\hline Total business assets & $\begin{array}{c}0.216 \\
(2.894)\end{array}$ & $\begin{array}{l}-0.063 \\
(2.931)\end{array}$ & $\begin{array}{c}0.014 \\
(2.926)\end{array}$ & $\begin{array}{c}0.046 \\
(2.916)\end{array}$ \\
\hline Profit & $\begin{array}{l}-7.732 \\
(5.245) \\
\end{array}$ & $\begin{array}{l}-6.432 \\
(5.208) \\
\end{array}$ & $\begin{array}{l}-6.662 \\
(5.295) \\
\end{array}$ & $\begin{array}{l}-6.824 \\
(5.347) \\
\end{array}$ \\
\hline \multicolumn{5}{|l|}{ Relationship Characteristics } \\
\hline Business age (in months) (a) & $\begin{array}{c}0.709 \\
(0.490)\end{array}$ & $\begin{array}{c}0.587 \\
(0.497)\end{array}$ & $\begin{array}{c}0.591 \\
(0.497)\end{array}$ & $\begin{array}{c}0.592 \\
(0.499)\end{array}$ \\
\hline $\begin{array}{l}\text { Relationship 2-5 } \\
\text { Years dummy (b) }\end{array}$ & $\begin{array}{c}23.806^{* * * *} \\
(9.049)\end{array}$ & $\begin{array}{c}12.190 \\
(11.160)\end{array}$ & $\begin{array}{c}16.954 \\
(14.398)\end{array}$ & $\begin{array}{c}13.068 \\
(11.370)\end{array}$ \\
\hline Relationship $>5$ years dummy (c) & $\begin{array}{l}44.359^{* * *} \\
(10.290)\end{array}$ & $\begin{array}{c}36.182^{* * *} \\
(11.717) \\
\end{array}$ & $\begin{array}{c}35.482^{* * *} \\
(11.976)\end{array}$ & $\begin{array}{l}31.998^{* *} \\
(14.998)\end{array}$ \\
\hline \multicolumn{5}{|l|}{ Islamic Relationship } \\
\hline Islamicdummy & & $\begin{array}{l}22.302^{* *} \\
(9.139)\end{array}$ & $\begin{array}{l}25.014^{* *} \\
(12.037)\end{array}$ & $\begin{array}{l}19.324^{*} \\
(10.518)\end{array}$ \\
\hline Interaction (a) x Islamic dummy & & & $\begin{array}{c}-8.077 \\
(18.252)\end{array}$ & \\
\hline Interaction (b) x Islamic dummy & & & & $\begin{array}{c}8.775 \\
(20.126)\end{array}$ \\
\hline Constant & $\begin{array}{c}211.267^{* * *} \\
(31.569)\end{array}$ & $\begin{array}{c}193.736^{* * *} \\
(32.000)\end{array}$ & $\begin{array}{c}194.602^{* * *} \\
(32.033)\end{array}$ & $\begin{array}{c}194.052^{* * *} \\
(31.938)\end{array}$ \\
\hline Observations & 1,001 & 1,001 & 1,001 & 1,001 \\
\hline Regional Fixed Effects & Yes & Yes & Yes & Yes \\
\hline
\end{tabular}

Based on the regression in Table 1, it can be seen that the relationship variables, especially the duration of more than five years, are significant. This provides evidence that overall, MFIs are able to utilise the relationship duration to reduce the asymmetric information problem and provide higher credit availability for borrowers (Petersen \& Rajan, 1994). This condition can improve, since it helps lenders to extract better information from borrowers. In column (1) in Table 2, it is shown that the coefficient of the relationship dummy variable of more than 5 years is 44.36 percent, which means that when the borrowers have a relationship of more than 5 years, the percentage of credit approved increases by 44.36 percent.

\subsubsection{Islamic Commercial Model}

The second model examines the notion that Islamic financing provides a higher percentage of credit approvals than the other. In column (2) in Table 2, Islamic financing has a coefficient of 22.30 percent, which indicates that the percentage of approved loan in Islamic financing is higher by 22.30 percentage points. 
Furthermore, in columns (3) and (4) of Table 2, we interact the Islamic dummy variables with the relationship variables to examine the advantage of Islamic financing in term of utilising the relationship between borrower and lender. The results show that the interaction variables, both the 2-5 year relationship dummy and that for a relationship of more than 5 years, have no significant affect on the credit availability in Islamic financing. This implies that, although the relationship variables in general affect credit availability, the effect is not significantly different between Islamic and non-Islamic financing.

The second model then examines the uniqueness of Islamic MFIs, which are separated into the Baitul Maal and Baitul Tamwil functions, and analyses the possible double-bottom line issue which may occur. The regression results are provided in Table 2. Following the previous basic regression, we interact this variable with the borrower wealth indicators, such as education level (column 2), average individual expenditure (column 3), and total individual assets owned (in column 4). In testing the second hypothesis, the models tend to show that MFIs do not prefer to finance the poorest segment of potential borrowers.

Table 3.

Second Model Regression Results

\begin{tabular}{lcccc}
\hline \multirow{2}{*}{ VARIABLE } & $\mathbf{( 1 )}$ & $\mathbf{( 2 )}$ & $\mathbf{( 3 )}$ & $\mathbf{( 4 )}$ \\
\cline { 2 - 5 } & $\begin{array}{c}\text { Loan } \\
\text { Amount }\end{array}$ & Loan Amount & $\begin{array}{c}\text { Loan } \\
\text { Amount }\end{array}$ & $\begin{array}{c}\text { Loan } \\
\text { Amount }\end{array}$ \\
\hline & & & & \\
\hline Individual Characteristics & & & -0.133 & -0.113 \\
\hline Age & -0.269 & -0.150 & $(0.389)$ & $(0.391)$ \\
& $(0.374)$ & $(0.395)$ & -13.208 & -12.578 \\
Women dummy & -11.287 & -12.797 & $(12.692)$ & $(12.683)$ \\
& $(12.516)$ & $(12.755)$ & -5.326 & -4.934 \\
Head of family dummy & -4.637 & -5.232 & $(11.711)$ & $(11.702)$ \\
& $(11.635)$ & $(11.743)$ & -0.927 & -0.496 \\
Education level (d) & -3.145 & -3.478 & $(3.767)$ & $(3.814)$ \\
& $(3.567)$ & $(3.618)$ & -15.252 & -7.790 \\
Average individual & -11.575 & -9.199 & $(12.685)$ & $(12.578)$ \\
expenditure (e) & $(12.406)$ & $(12.425)$ & $-5.358^{*}$ & $-7.870^{* *}$ \\
Total individual assets & -4.902 & $-5.444^{*}$ & $(3.140)$ & $(3.179)$ \\
owned (f) & $(3.106)$ & $(3.142)$ & & \\
\hline Business Characteristics & & & -0.507 & -0.311 \\
\hline Number of employees & -0.670 & -0.683 & $(2.373)$ & $(2.408)$ \\
& $(2.199)$ & $(2.306)$ & 3.342 & 3.041 \\
Total sales & 3.806 & 3.384 & $(5.293)$ & $(5.339)$ \\
& $(5.239)$ & $(5.285)$ & -0.190 \\
Total business assets & 0.216 & 0.239 & 0.063 & $(2.948)$ \\
& $(2.894)$ & $(2.920)$ & $(2.932)$ & -6.348 \\
Profit & -7.732 & -6.976 & -6.807 & $(5.225)$ \\
\hline & $(5.245)$ & $(5.188)$ & $(5.218)$ &
\end{tabular}


Table 3.

Second Model Regression Results (Continued)

\begin{tabular}{|c|c|c|c|c|}
\hline & (1) & (2) & (3) & (4) \\
\hline VARIABLE & $\begin{array}{c}\text { Loan } \\
\text { Amount }\end{array}$ & Loan Amount & $\begin{array}{c}\text { Loan } \\
\text { Amount }\end{array}$ & $\begin{array}{c}\text { Loan } \\
\text { Amount }\end{array}$ \\
\hline \multicolumn{5}{|c|}{ Relationship Characteristics } \\
\hline Business age (in months) & $\begin{array}{c}0.709 \\
(0.490)\end{array}$ & $\begin{array}{c}0.638 \\
(0.492)\end{array}$ & $\begin{array}{c}0.591 \\
(0.500)\end{array}$ & $\begin{array}{c}0.584 \\
(0.500)\end{array}$ \\
\hline Relationship 2-5 & $23.806^{* * *}$ & 14.476 & 13.894 & 11.987 \\
\hline Years dummy & $(9.049)$ & $(10.832)$ & $(10.923)$ & $(10.989)$ \\
\hline Relationship $>5$ & $44.359^{* * *}$ & $37.132^{* * *}$ & $37.222^{* * *}$ & $37.456^{* * *}$ \\
\hline Years dummy & $(10.290)$ & $(11.616)$ & $(11.593)$ & $(11.480)$ \\
\hline \multicolumn{5}{|l|}{ Islamic Commercial Model } \\
\hline \multicolumn{5}{|l|}{ Islamic dummy } \\
\hline Interaction $(\mathrm{d}) \mathrm{x}$ & & $5.157^{*}$ & & \\
\hline Islamic dummy & & $(2.695)$ & & \\
\hline Interaction (e) $x$ & & & $12.463^{* *}$ & \\
\hline Islamic dummy & & & $(5.561)$ & \\
\hline Interaction $(\mathrm{f}) \mathrm{x}$ & & & & $4.844^{* * *}$ \\
\hline Islamic dummy & & & & $(1.676)$ \\
\hline Constant & $\begin{array}{c}211.267^{* * *} \\
(31.569)\end{array}$ & $\begin{array}{c}204.948^{* * *} \\
(31.721)\end{array}$ & $\begin{array}{c}204.469^{* * *} \\
(31.283)\end{array}$ & $\begin{array}{c}200.705^{* * *} \\
(31.396)\end{array}$ \\
\hline Observations & 1,001 & 1,001 & 1,001 & 1,001 \\
\hline Regional Fixed Effects & Yes & Yes & Yes & Yes \\
\hline
\end{tabular}

Source: Authors' elaboration (2019)

The regression results in Table 2 show that most of the individual wealth indicators do not have a significant affect on credit availability (column 1). The results indicate that credit wealth does not determine MFI credit availability in general. The hypothesis that MFI financing currently focus on profitability due to concerns over the borrowers' wealth and repayment capacity is therefore rejected. In column 2, we interact the dummy Islamic variable with the educational level variable. The interaction variable is significant at the $10 \%$ level. The results show that an increase of one education level in Islamic financing will increase the number of approved loans by 5.157 percent compared to non-Islamic financing. In column 3 , the coefficient of average individual expenditure is also significant at the $5 \%$ level, implying that an increase in average individual expenditure in one category would increase the number of approved loans in Islamic financing by 12.463 percent compared to non-Islamic financing. Finally, in column 4 a significant effect of the assets owned by borrowers on credit availability is also found, indicating that a greater level of assets will increase the number of approved loans by Islamic MFIs by 4.844 percent, compared to the percentage of approved loans by nonIslamic MFIs. 


\subsection{Analysis}

Based on the results in the previous section, it can be interpreted that Islamic financing tends to have higher credit availability for borrowers. This is in line with previous research, which has also found that Islamic finance provides higher financing for small businesses (Shaban et al., 2014).

In order to examine the reasons for this positive effect, two models were developed using interaction variables between the Islamic dummy and some variables. First, the Islamic dummy is interacted with the relationship between borrower and lender in order to observe the relationship effect as the source of the positive Islamic dummy effect. This is also in line with previous research which has suggested that a strong relationship between borrower and lender tends to reduce asymmetric information (Berger \& Udell, 1995). In addition, another study found that borrowers prefer to receive relationship benefits through credit availability instead of lower interest rates (Petersen \& Rajan, 1994). Specifically, Islamic MFIs provide better monitoring to eliminate asymmetric information since they make deals with families rather than individuals. This mitigates the possibility that funds are used for the actual purpose. Moreover, Islamic financing involves real transactions, which helps to decrease moral hazard (Ahmed, 2002).

However, we find no significant effect from the interaction between the Islamic financing dummy and relationship variables. This means that the positive effect of Islamic finance does not originate from the relationship variable since there are no differences between Islamic and non-Islamic financing. Islamic financing cannot extract additional information from the interaction with their borrowers than nonIslamic financing. It is hard to find related literature to support the insignificant effect of the relationship variable in Islamic MFIs on credit availability, while Islamic MFIs tend to have positive significant effect. This indicates that the relationship effect does not differ between Islamic and non-Islamic financing. The results also show the possibility that there is another factor that results in the greater credit availability in Islamic financing.

Regarding the insignificant effect of better relationships with borrowers, we suggest that the possible explanation for this finding is that commercial financing operated by Islamic MFIs tends to be more profit-oriented compared to nonIslamic MFIs (Ascarya, 2018). Islamic MFIs are able to optimise their transactions by financing wealthier borrowers in order to make more profits through lower risk and larger loan size (Armendariz \& Szafarz, 2011). This situation is the consequence of the Islamic MFI concept of having two institutions, namely Baitul Maal and Baitut Tamwil; whereas Baitul Maal focuses on operating social activities, Baitut Tamwil focuses on lending using the concept of commercial financing.

Therefore, in the second model, the hypothesis is examined by analysing the interaction between Islamic financing and borrower wealth. While the basic model shows that borrower wealth is not significant, the interaction variables between the Islamic dummy and such wealth have a significant positive effect. This supports the distinction between Islamic and non-Islamic MFIs, with Islamic MFIs financing through Baitul Tamwil considered to be fully profit-oriented. This situation might have arisen due to the fact that the socially-oriented activities have been conducted by Baitul Maal, a separate institution in Islamic MFIs. Baitul Maal helps the poorest people through the zakah instrument, which is entirely socially- 
oriented (Ascarya, 2018). In addition, cash loans for micro enterprises have been developed as profit-oriented products which differ from "traditional microcredit" (e.g., the Grameen Bank). The products are aimed at providing financial support for the unfulfilled demand among MSEs (Karlan \& Zinman, 2009).

This finding confirms that there are the differences between Islamic and nonIslamic MFIs. As opposed to conventional microfinance, BMT is the most suitable model of IMFI as it can achieve the complete triple bottom-line (sustainability, outreach and welfare impacts (Ascarya, 2018). BMT is unique because it integrates both Islamic commercial and social finance functions with the existence of Baitul Maal and Baitul Tamwil to create holistic financial inclusion (Ascarya, 2016). Ascarya (2018) explains that prior to managing zakah, infaq, sadaqah and waqf (ZIS-Waf) funds, BMTs mostly rely on Islamic banks to meet their funding needs. However, after obtaining a nadzir (administrator) license for cash waqf and for managing ZIS funds, BMTs can operate with cash waqf as an alternative source of funding and consequently improve their liquidity. In addition, there is some evidence that wealthier borrowers tend to move from mustahiq to muzakki since they tend to pay waqf, a non-obligatory infaq (Wulandari \& Robbani, 2019). This indicates that Islamic financing from BMTs is directed to the right people and fits with the notion of profit-oriented financing.

There are some caveats in our research. First, there is the possibility that profit orientation may lead to mission drift, in which micro-finance needs are focused more on outreach than on loan size (Simatele \& Dlamini, 2019). However, the unique Islamic scheme, which integrates social and commercial activities in BMT, means mission drift is not an issue. Furthermore, Tamanni and Haji Besar (2019) found that larger loan sizes do not lead to mission drift, since loan size mostly depends on the size of the MFI.

In addition, average loan size, as employed in our approach, has been criticised by Mersland and Strøm (2010), since other factors such as average cost and profit could increase it. Therefore, another robustness test using an alternative indicator would be beneficial to confirm our results, as discussed in section 4.3.

\subsection{Robustness Test}

Based on the results in the previous section, a robustness test was conducted using Probit regression. In this test, we changed the dependent variable to a dummy variable instead of a percentage. This variable is equal to 1 when borrowers receive the amount that they have requested, and 0 otherwise. Probit regression was then performed to censor the fitted value between 0 until 1. 
Table 4.

First Model Robustness Regression Results

\begin{tabular}{|c|c|c|c|c|}
\hline & (1) & (2) & (3) & (4) \\
\hline VARIABLE & $\begin{array}{c}\text { Loan } \\
\text { Amount }\end{array}$ & $\begin{array}{c}\text { Loan } \\
\text { Amount }\end{array}$ & $\begin{array}{c}\text { Loan } \\
\text { Amount }\end{array}$ & $\begin{array}{c}\text { Loan } \\
\text { Amount }\end{array}$ \\
\hline \multicolumn{5}{|l|}{ Individual Characteristics } \\
\hline Age & $\begin{array}{l}-0.000 \\
(0.001)\end{array}$ & $\begin{array}{c}0.000 \\
(0.001)\end{array}$ & $\begin{array}{c}0.000 \\
(0.001)\end{array}$ & $\begin{array}{c}0.000 \\
(0.001)\end{array}$ \\
\hline Women dummy & $\begin{array}{l}-0.016 \\
(0.031)\end{array}$ & $\begin{array}{l}-0.020 \\
(0.031)\end{array}$ & $\begin{array}{l}-0.021 \\
(0.031)\end{array}$ & $\begin{array}{l}-0.021 \\
(0.031)\end{array}$ \\
\hline Head of family dummy & $\begin{array}{l}-0.007 \\
(0.030)\end{array}$ & $\begin{array}{l}-0.008 \\
(0.030)\end{array}$ & $\begin{array}{l}-0.008 \\
(0.030)\end{array}$ & $\begin{array}{l}-0.008 \\
(0.030)\end{array}$ \\
\hline Education level & $\begin{array}{l}-0.006 \\
(0.009)\end{array}$ & $\begin{array}{c}0.002 \\
(0.010)\end{array}$ & $\begin{array}{c}0.002 \\
(0.010)\end{array}$ & $\begin{array}{c}0.002 \\
(0.010)\end{array}$ \\
\hline Average individual expenditure & $\begin{array}{l}-0.029 \\
(0.032)\end{array}$ & $\begin{array}{l}-0.018 \\
(0.033)\end{array}$ & $\begin{array}{l}-0.018 \\
(0.033)\end{array}$ & $\begin{array}{l}-0.018 \\
(0.033)\end{array}$ \\
\hline Total individual assets owned & $\begin{array}{l}-0.015^{*} \\
(0.008)\end{array}$ & $\begin{array}{c}-0.017^{* *} \\
(0.008)\end{array}$ & $\begin{array}{c}-0.017^{* *} \\
(0.008)\end{array}$ & $\begin{array}{l}-0.017^{* *} \\
(0.008)\end{array}$ \\
\hline \multicolumn{5}{|l|}{ Business Characteristics } \\
\hline Number of employees & $\begin{array}{l}-0.004 \\
(0.005)\end{array}$ & $\begin{array}{l}-0.003 \\
(0.006)\end{array}$ & $\begin{array}{l}-0.003 \\
(0.006)\end{array}$ & $\begin{array}{l}-0.003 \\
(0.006)\end{array}$ \\
\hline Total sales & $\begin{array}{c}0.015 \\
(0.013)\end{array}$ & $\begin{array}{c}0.013 \\
(0.013)\end{array}$ & $\begin{array}{c}0.013 \\
(0.013)\end{array}$ & $\begin{array}{c}0.013 \\
(0.013)\end{array}$ \\
\hline Total business assets & $\begin{array}{c}0.003 \\
(0.007)\end{array}$ & $\begin{array}{c}0.002 \\
(0.007)\end{array}$ & $\begin{array}{c}0.002 \\
(0.007)\end{array}$ & $\begin{array}{c}0.002 \\
(0.007)\end{array}$ \\
\hline Profit & $\begin{array}{l}-0.023^{*} \\
(0.013) \\
\end{array}$ & $\begin{array}{c}-0.018 \\
(0.013) \\
\end{array}$ & $\begin{array}{l}-0.018 \\
(0.013) \\
\end{array}$ & $\begin{array}{l}-0.019 \\
(0.013) \\
\end{array}$ \\
\hline \multicolumn{5}{|l|}{ Relationship Characteristics } \\
\hline Business age (in months) (a) & $\begin{array}{l}0.002^{*} \\
(0.001)\end{array}$ & $\begin{array}{c}0.002 \\
(0.001)\end{array}$ & $\begin{array}{c}0.002 \\
(0.001)\end{array}$ & $\begin{array}{c}0.002 \\
(0.001)\end{array}$ \\
\hline $\begin{array}{l}\text { Relationship 2-5 years dummy } \\
\text { (b) }\end{array}$ & $\begin{array}{l}0.072^{* * *} \\
(0.023)\end{array}$ & $\begin{array}{c}0.029 \\
(0.027)\end{array}$ & $\begin{array}{c}0.031 \\
(0.037)\end{array}$ & $\begin{array}{c}0.030 \\
(0.028)\end{array}$ \\
\hline $\begin{array}{l}\text { Relationship }>5 \text { years dummy } \\
\text { (c) }\end{array}$ & $\begin{array}{c}0.113^{* * *} \\
(0.025)\end{array}$ & $\begin{array}{c}0.081^{* * *} \\
(0.028)\end{array}$ & $\begin{array}{c}0.081^{* * *} \\
(0.028)\end{array}$ & $\begin{array}{l}0.077^{* *} \\
(0.036)\end{array}$ \\
\hline \multicolumn{5}{|l|}{ Islamic Relationship } \\
\hline Islamic dummy & & $\begin{array}{c}0.079^{* * *} \\
(0.024)\end{array}$ & $\begin{array}{l}0.080^{* * *} \\
(0.029)\end{array}$ & $\begin{array}{c}0.076^{* * *} \\
(0.027)\end{array}$ \\
\hline Interaction (a) x Islamic dummy & & & $\begin{array}{l}-0.003 \\
(0.045)\end{array}$ & \\
\hline Interaction (b) x Islamic dummy & & & & $\begin{array}{c}0.010 \\
(0.049)\end{array}$ \\
\hline Observations & 1,001 & 1,001 & 1,001 & 1,001 \\
\hline Regional Fixed Effects & Yes & Yes & Yes & Yes \\
\hline
\end{tabular}

Source: Authors' elaboration (2019) 
Table 4 shows the results from the robustness test, from which the significances of the variables are seen to be similar to those of the main model. The Islamic dummy is significant, while the interaction with the relationship variable is not significant. This confirms that the relationship between borrower and the lender is not the main factor that results in the positive effect of the Islamic dummy.

Table 5.

Second Model Robustness Regression Results

\begin{tabular}{|c|c|c|c|c|}
\hline & (1) & (2) & (3) & (4) \\
\hline VARIABLE & $\begin{array}{c}\text { Loan } \\
\text { Amount }\end{array}$ & $\begin{array}{c}\text { Loan } \\
\text { Amount }\end{array}$ & $\begin{array}{c}\text { Loan } \\
\text { Amount }\end{array}$ & $\begin{array}{c}\text { Loan } \\
\text { Amount }\end{array}$ \\
\hline \multicolumn{5}{|l|}{ Individual Characteristics } \\
\hline Age & $\begin{array}{l}-0.000 \\
(0.001)\end{array}$ & $\begin{array}{c}0.000 \\
(0.001)\end{array}$ & $\begin{array}{c}0.000 \\
(0.001)\end{array}$ & $\begin{array}{c}0.000 \\
(0.001)\end{array}$ \\
\hline Women dummy & $\begin{array}{l}-0.016 \\
(0.031)\end{array}$ & $\begin{array}{l}-0.021 \\
(0.031)\end{array}$ & $\begin{array}{l}-0.022 \\
(0.031)\end{array}$ & $\begin{array}{l}-0.020 \\
(0.031)\end{array}$ \\
\hline Head of family dummy & $\begin{array}{l}-0.007 \\
(0.030)\end{array}$ & $\begin{array}{l}-0.009 \\
(0.030)\end{array}$ & $\begin{array}{l}-0.009 \\
(0.030)\end{array}$ & $\begin{array}{l}-0.008 \\
(0.030)\end{array}$ \\
\hline Education level (d) & $\begin{array}{l}-0.006 \\
(0.009)\end{array}$ & $\begin{array}{l}-0.007 \\
(0.009)\end{array}$ & $\begin{array}{c}0.002 \\
(0.010)\end{array}$ & $\begin{array}{c}0.003 \\
(0.010)\end{array}$ \\
\hline Average individual expenditure (e) & $\begin{array}{l}-0.029 \\
(0.032)\end{array}$ & $\begin{array}{l}-0.019 \\
(0.032)\end{array}$ & $\begin{array}{l}-0.041 \\
(0.033)\end{array}$ & $\begin{array}{l}-0.015 \\
(0.033)\end{array}$ \\
\hline Total individual assets owned (f) & $\begin{array}{l}-0.015^{*} \\
(0.008)\end{array}$ & $\begin{array}{l}-0.017^{* *} \\
(0.008)\end{array}$ & $\begin{array}{l}-0.016^{* *} \\
(0.008)\end{array}$ & $\begin{array}{c}-0.025^{* * *} \\
(0.008) \\
\end{array}$ \\
\hline \multicolumn{5}{|l|}{ Business Characteristics } \\
\hline Number of employees & $\begin{array}{l}-0.004 \\
(0.005)\end{array}$ & $\begin{array}{l}-0.004 \\
(0.006)\end{array}$ & $\begin{array}{l}-0.003 \\
(0.006)\end{array}$ & $\begin{array}{l}-0.002 \\
(0.006)\end{array}$ \\
\hline Total sales & $\begin{array}{c}0.015 \\
(0.013)\end{array}$ & $\begin{array}{c}0.013 \\
(0.013)\end{array}$ & $\begin{array}{c}0.013 \\
(0.013)\end{array}$ & $\begin{array}{c}0.012 \\
(0.013)\end{array}$ \\
\hline Total business assets & $\begin{array}{c}0.003 \\
(0.007)\end{array}$ & $\begin{array}{c}0.003 \\
(0.007)\end{array}$ & $\begin{array}{c}0.003 \\
(0.007)\end{array}$ & $\begin{array}{c}0.002 \\
(0.007)\end{array}$ \\
\hline Profit & $\begin{array}{l}-0.023^{*} \\
(0.013)\end{array}$ & $\begin{array}{l}-0.020 \\
(0.013)\end{array}$ & $\begin{array}{l}-0.019 \\
(0.013)\end{array}$ & $\begin{array}{l}-0.018 \\
(0.013)\end{array}$ \\
\hline \multicolumn{5}{|l|}{ Relationship Characteristics } \\
\hline Business age (in months) & $\begin{array}{l}0.002^{*} \\
(0.001)\end{array}$ & $\begin{array}{c}0.002 \\
(0.001)\end{array}$ & $\begin{array}{c}0.002 \\
(0.001)\end{array}$ & $\begin{array}{c}0.002 \\
(0.001)\end{array}$ \\
\hline Relationship 2-5 years dummy & $\begin{array}{c}0.072 * * * \\
(0.023)\end{array}$ & $\begin{array}{c}0.036 \\
(0.027)\end{array}$ & $\begin{array}{c}0.036 \\
(0.027)\end{array}$ & $\begin{array}{c}0.030 \\
(0.027)\end{array}$ \\
\hline Relationship $>5$ years dummy & $\begin{array}{c}0.113^{* * * *} \\
(0.025) \\
\end{array}$ & $\begin{array}{c}0.084^{* * *} \\
(0.027) \\
\end{array}$ & $\begin{array}{l}0.085^{* * *} \\
(0.027) \\
\end{array}$ & $\begin{array}{l}0.087^{* * *} \\
(0.027) \\
\end{array}$ \\
\hline \multicolumn{5}{|l|}{ Islamic Commercial Model } \\
\hline Islamic dummy & & & & \\
\hline Interaction (d) x Islamic dummy & & $\begin{array}{c}0.019^{* * *} \\
(0.007)\end{array}$ & & \\
\hline Interaction (e) x Islamic dummy & & & $\begin{array}{c}0.044^{* * *} \\
(0.014)\end{array}$ & \\
\hline Interaction (f) $x$ Islamic dummy & & & & $\begin{array}{c}0.016^{* * *} \\
(0.004)\end{array}$ \\
\hline Observations & 1,001 & 1,001 & 1,001 & 1,001 \\
\hline MFI Fixed Effects & Yes & Yes & Yes & Yes \\
\hline
\end{tabular}

Source: Authors' elaboration (2019) 
Table 5 shows the results from second model robustness test, from which it can be seen that the significances of the variables are also similar to those of the main model. All the interaction variables between the Islamic dummy and borrower wealth are significant. This confirms that MFIs may be concerned about their profitability due to the positive effect of borrower wealth on Islamic MFIs.

\section{CONCLUSION AND RECOMMENDATIONS}

\subsection{Conclusion}

The main goals of this study were to explore the sources of larger loan sizes from Islamic MFI financing, namely the effectiveness of relationship lending and the state of Islamic MFIs being more profit oriented. The findings of the paper show that Islamic MFIs are likely to provide greater credit availability than conventional MFIs. This supports the findings of Shaban et al. (2014), that Islamic finance institutions provide higher financing for small business. On the other hand, no significant difference was found between Islamic and conventional MFIs with regard to their relationship with the relationship lending variable. Therefore, the findings suggest that the significant effect of Islamic MFI financing may be caused by another factor.

The results from the second model provide evidence that Islamic MFIs tend to optimise their commercial mission by financing more profitable borrowers. The separation between their social and commercial missions helps them to attract better borrowers than non-Islamic MFIs. Moreover, the results elaborate the alternative way of addressing triple-bottom line issues in microfinancing institutions.

Furthermore, based on the findings, Islamic MFIs provide greater credit availability to MSEs and there are positive relationships between Islamic MFIs and the wealth variables. These results could possibly be explained by the fact that Islamic MFIs can focus on commercial financing because their socially-oriented activities are distributed through the socially-oriented instruments in the Baitut Maal section. An additional robustness test was performed to examine the results of our model. Therefore, it is likely that these results are due to Islamic MFIs' preference for obtaining more profit or pursuing sustainability by financing customers with lower risk and larger loan sizes. This is an expected indicator of the occurrence of a distinctive financing mechanism in Islamic MFIs.

\subsection{Recommendations}

The research extends our knowledge of various important issues in Islamic MFIs, namely the relationship lending variable and the MFIs' uniqueness in integrating the Baitul Maal social functions and the Baitul Tamwil commercial functions. The findings of the study should be beneficial for regulators and Islamic MFIs themselves to confirm the different mechanism in place. Regulators can improve the governance of Islamic MFIs in particular in order to strengthen the role of Baitul Maal in pursuing their mission to eradicate poverty, while focusing on monitoring Baitul Tamwil as a commercial MFI arm, since this scheme can address the commercial and social missions of MFIs simultaneously. Additionally, policymakers could offer other incentives for MFIs to enable them to have a deep 
outreach into the poorest segments of the population. Since this study does not include the Baitul Maal instruments, it would be interesting to investigate the effect of these on credit availability in order to examine the possibility of mission drift. Therefore, future research could address the issue of zakah disbursement, which is the function of Baitul Maal in controlling the effect of social activities in Islamic MFIs.

\section{ACKNOWLEDGEMENTS}

We would like to thank our colleagues from UKM Center FEB UI, who provided insights and data that greatly assisted the research, although they may not agree with all the interpretations/conclusions of the paper. We also thank T. M. Zakir Sjakur Machmud and Permata Wulandari for their discussions which helped to enrich the explanations in the paper.

\section{REFERENCES}

Agarwal, S., Chomsisengphet, S., Liu, C., Song, C., \& Souleles, N. S. (2018). Benefits of Relationship Banking: Evidence from Consumer Credit Markets. Journal of Monetary Economics, 96, 16-32.

Ahmed, H. (2002). Financing Microenterprises: An Analytical Study of Islamic Microfinance Institutions. Islamic Economic Studies, 9(2), 27-64.

Aigbokhan, B. E., \& Asemota, A. E. (2011). An Assessment of Microfinance as a Tool for Poverty Reduction and Social Capital Formation: Evidence on Nigeria. Global Journal of Finance and Banking, 5(5), 38-48.

Armendariz, B., \& Szafarz, A. (2011). On Mission Drift in Microfinance Institutions. In The Handbook of Microfinance (pp. 341-366). Singapore: World Scientific Publishing.

Ascarya (2016). Holistic Financial Inclusion Based on Maqashid Shariah Through Baitul Maal Wat Tamwil. In Middle East Insights (pp. 1-8). Singapore: Middle East Institute, National University of Singapore.

Ascarya (2018). Baitul Maal wat Tamwil (BMT): An Integrated Islamic Social and Commercial Financial Institution in Indonesia. In Islamic Commercial Law Report 2018 (pp. 104-107). Retrieved from https:/ceif.iba.edu.pk/pdf/ ThomsonReutersIslamicCommercialLawReport2018.pdf

Ascarya, \& Sanrego, Y. D. (2007). Redefine Micro , Small and Medium Enterprises Classification and The Potency Of Baitul Maal Wa Tamwiel as Intermediary Institutions in Indonesia. International Conference on Inclusive Islamic Financial Sector Development. Negara Brunei Darussalam: UBD-IRTI.

Bank Indonesia. (2015). Profil Bisnis Usaha Mikro, Kecil dan Menengah (UMKM) Kerjasama LPPI dengan Bank Indonesia Tahun 2015. DKI Jakarta: Bank Indonesia.

Beck, T., Kunt, A. D., \& Levine, R. (2005). SMEs , Growth , and Poverty : CrossCountry Evidence. Journal of Economic Growth, 10, 199-229.

Berger, A. N., \& Udell, G. F. (1995). Relationship Lending and Lines of Credit in Small Firm Finance. The Journal of Business, 68(3), 351-381. 
Berger, A. N., \& Udell, G. F. (2002). Small Business Credit Availability and Relationship Lending: The Importance of Bank Organisational Structure. Economic Journal, 112(477), F32-F53.

Chalid, D. A., Sulung, L. A. K., Robbani, M. M., \& Hambali, M. (2019). National Framework, Market Structure, and Bank Stability: Evidences from ASEAN-5 Countries. Pertanika Journal of Social Sciences \& Humanities, 27(S(2)), 17-32.

Cornforth, C. (2014). Understanding and Combating Mission Drift in Social Enterprises. Social Enterprise Journal, 10(1), 3-20.

Diamond, D. W. (1984). Financial Intermediation and Delegated Monitoring. The Review of Economic Studies, 51(3), 393-414.

Diamond, D. W. (1991). Monitoring and Reputation: The Choice between Bank Loans and Directly Placed Debt. Journal of Political Economy, 99(4), 689-721.

Ferri, G., Murro, P., \& Pini, M. (2020). Credit Rationing and the Relationship between Family Businesses and Banks in Italy. Global Finance Journal, 43(February), 100427.

Foose, L., \& Greenberg, A. (2008). The Double Bottom Line: Evaluating Social Performance in Microfinance. Microbanking Bulletin, (17), 12-16.

Hassan, M. K., \& Renteria-Guerrero, L. (1997). The Experience of the Grameen Bank of Bangladesh in Community Development. International Journal of Social Economics, 24(12), 1488-1523.

Hiatt, S. R., \& Woodworth, W. P. (2006). Alleviating Poverty through Microfinance: Village Banking Outcomes in Central America. Social Science Journal, 43(3), 471-477.

Hu, H., Lian, Y., \& Su, C. H. (2016). Do Bank Lending Relationships Affect Corporate Cash Policy? Review of Accounting and Finance, 15(4), 394-415.

Imai, K., Gaiha, R., Thapa, G., \& Annim, S. K. (2012). Economics Discussion Paper Series Microfinance and Poverty A Macro Perspective Katsushi Imai Raghav Gaiha Ganesh Thapa. World Development, 40(8), 1675-1689.

Karlan, D., \& Zinman, J. (2009). Observing Unobservables: Identifying Information Asymmetries with a Consumer Credit Field Experiment. Econometrica, 77(6), 1993-2008.

Khandker, S. R. (2005). Microfinance and Poverty: Evidence Using Panel Data from Bangladesh. The World Bank Economic Review, 19(2), 263-286.

Kinsey, J. (1981). Determinants of Credit Card Accounts: An Application of Tobit Analysis. Journal of Consumer Research, 8(2), 172-182.

Korth, M., Stewart, R., Van Rooyen, C., \& De Wet, T. (2012). Microfinance: Development Intervention or Just Another Bank? Journal of Agrarian Change, 12(4), 575-586.

López-Espinosa, G., Mayordomo, S., \& Moreno, A. (2017). When Does Relationship Lending Start to Pay? Journal of Financial Intermediation, 31, 16-29.

Masyita, D., \& Ahmed, H. (2013). Why is Growth of Islamic Microfinance Lower than its Conventional Counterparts in Indonesia? Islamic Economic Studies, 21-1, 35-62.

Mersland, R., \& Strøm, R. Ø. (2010). Microfinance Mission Drift? World Development, 38(1), 28-36. 
Ministry of Cooperation and Small and Medium Enterprise of The Republic of Indonesia. (2017). Data development of micro, small, medium, and big enterprises 2016-2017. (1), 2016-2017.

Moffitt, R. A. (1999). Chapter 24 New developments in econometric methods for labor market analysis. In Handbook of Labor Economics: Vol. 3 PART (pp. 13671397). https://doi.org/10.1016/S1573-4463(99)03005-9

Naceur, S. Ben, Barajas, A., \& Massara, A. (2015). OKUNDU_24.02.2018_Can Islamic Banking Increase Financial Inclusion ? IMF Working Paper, 1-41. https:// doi.org/10.1016/j.siny.2015.07.001

Obaidullah, M. (2008). Introduction to Islamic Microfinance. India: International Institute of Islamic Business and Finance.

Olagunju, F., \& Ajiboye, A. (2010). Agricultural Lending Decision: a Tobit Regression Analysis. African Journal of Food, Agriculture, Nutrition and Development, 9(1), 76-99. https://doi.org/10.1558/jsrnc.v4il.24

Petersen, M. A., \& Rajan, R. G. (1994). The Benefits of Lending Relationships: Evidence from Small Business Data. The Journal of Finance, 49(1), 3-37. https:// doi.org/10.2307/2329133

Robbani, M. M., Anggriyani, D. S., Sekardhani, M., \& Nikmah, U. (2019). UKM Tak Tersentuh Bank. Depok: UKM Center FEB UI.

Schuite, G. J., \& Pater, A. (2008). The Triple Bottom Line for Microfinance. London, UK: Enclude.

Seibel, H. D. (2008). Islamic Microfinance in Indonesia: The Challenge of Institutional Diversity, Regulation, and Supervision. SOJOURN: Journal of Social Issues in Southeast Asia, 23(1), 86-103.

Shaban, M., Duygun, M., Anwar, M., \& Akbar, B. (2014). Diversification and Banks' Willingness to Lend to Small Businesses: Evidence from Islamic and Conventional Banks in Indonesia. Journal of Economic Behavior and Organization, 103(Supplement), S39-S55. https://doi.org/10.1016/j.jebo.2014.03.021

Simatele, M., \& Dlamini, P. (2019). Finance and the Social Mission: a Quest for Sustainability and Inclusion. Qualitative Research in Financial Markets, ahead-ofp(ahead-of-print). https://doi.org/10.1108/QRFM-02-2019-0024

Tamanni, L., \& Haji Besar, M. H. A. (2019). Profitability vs Poverty Alleviation: Has Banking Logic Influences Islamic Microfinance Institutions? Asian Journal of Accounting Research, ahead-of-p(ahead-of-print). https://doi.org/10.1108/ajar05-2019-0039

Weiss, J., \& Montgomery, H. (2005). Great Expectations: Microfinance and Poverty Reduction in Asia and Latin America. Oxford Development Studies, 33(3-4), 391-416. Retrieved from https://www.adb.org/sites/default/files/ publication/157174/adbi-rp63.pdf

Wijaya, I. F., Hakim, A. R., Saputro, N., \& Mulyadi, M. (2019). Religiosity Level and Saving Decisions in Baitul Maal wat Tamwil: the Case of Indonesia. Journal of Islamic Marketing. https://doi.org/10.1108/JIMA-09-2018-0160

Wulandari, P. (2019). Enhancing the Role of Baitul Maal in Giving Qardhul Hassan Financing to the Poor at the Bottom of the Economic Pyramid: Case Study of Baitul Maal wa Tamwil in Indonesia. Journal of Islamic Accounting and Business Research, 10(3), 382-391. https://doi.org/10.1108/JIABR-01-2017-0005 
Wulandari, P., \& Robbani, M. M. (2019). Does Religiosity and Socio-Economic Aspects Influence Zakat and Waqf Payment? (Case Study of Ultra Micro SMEs in Indonesia Baitul Maal Wa Tamwil). In Revitalization of Waqffor Socio-Economic Development, (Vol. 2, pp. 269-292). Springer.

Yahaya, K. A., Osemene, O. F., \& Abdulraheem, A. (2011). Effectiveness of Microfinance Banks in Alleviating Poverty in Kwara State Nigeria. Global Journal of Management and Business Research, 11(4), 13-20.

Zeller, M., \& Meyer, R. L. (2002). The Triangle of Microfinance: Financial Sustainability, Outreach, and Impact. Washington: IFPRI. 
This page is intentionally left blank 